\title{
CD79A Expressing Cell Count
}

National Cancer Institute

\section{Source}

National Cancer Institute. CD79A Expressing Cell Count. NCI Thesaurus. Code C111152.

The determination of the amount of CD79A expressing cells per unit present in a sample. 